\title{
GLACIERS IN THE NORTH-EASTERN PART OF THE CH'ING-HAI-HSI-TSANG (QINGHAI-XIZANG) PLATEAU (TIBET) AND THEIR VARIATIONS
}

\author{
By WANG WENYING* \\ (Lanzhou Institute of Glaciology and Cryopedology, Academia Sinica, Lan-chou (Lanzhou), \\ Kansu (Gansu), 730000, China)
}

\begin{abstract}
The first extensive and far-reaching investigations of the Sino-German Joint Expedition to the Ch'ing-hai-Hsi-tsang (Qinghai-Xizang) Plateau in the glacierized region of the Amne Machin (Anyemaqen) started work in the area and compiled the glacial inventory in that region. In the past 15 years scientists have found that the majority of glaciers in the Amne Machin (Anyemaqen) have been advancing whereas most glaciers in Ch'i-lien Shan (Qilian Shan), adjacent to Amne Machin (Anyemaqen), have been retreating during the same period. This is a problem worthy of study by glaciologists. Through investigation and analysis, it is also found that Ha-lung (Halong) glacier has the character of a surging glacier. The author tentatively forecasts the next surge of Ha-lung (Halong) glacier and the tendency of variations of glaciers in Ch'i-lien Shan (Qilian Shan) in the near future.
\end{abstract}

RÉSUMÉ. Les glaciers du nord-est du plateau du Ch'ing-hai-Hsi-tsang (Qinghai-Xizang) (Tibet) et leurs variations. Les premières recherches complètes et lointaines de l'Expédition commune sino-germanique sur le plateau tibètain dans la région glaciaire de l'Amne Machin (Anyemaqen) a accompli un réel travail et a ètabli l'inventaire des glaciers de ce secteur. Les chercheurs ont constaté qu'au cours des 15 dernières années, la majorité des glaciers de l'Amne Machin (Anyemaqen) ont été en crue et que la plupart des glaciers du Ch'i-lien Shan (Qilian Shan), voisin de Amne Machin (Anyemaqen), ont été en décrue pendant la même période. Il y a là un bon sujet d'étude pour les glaciologues. Au cours des recherches et analyses, il est apparu aussi que le glacier Ha-lung (Halong) a le caractère d'un glacier à crues subites. L'auteur tente de prévoir la prochaine crue du glacier Ha-lung (Halong) et la tendance des variations des glaciers du Ch'i-lien Shan (Qilian Shan) dans le proche futur.

Zusammenfassung. Gletscher im Nordteil des Ch'ing-hai-Hsi-tsang (Qinghai-Xizang)-Plateaus (Tibet) und ihre Schwankungen. Die erste umfassend und weitreichende Untersuchung der gemeinsamen ChinesischDeutschen Expedition auf das Ch'ing-hai-Hsi-tsang (Qinghai-Xizang)-Plateau zum Gletscherfeld in den Amne Machin (Anyemaqen) führte zu aktuellen Arbeiten und vermittelte das Gletscherinventar in diesem Gebiet. Die Wissenschaftler stellten fest, dass die Mehrzahl der Gletscher in den Amne Machin (Anyemaqen) während der letzten 15 Jahre vorgestossen ist, dass aber die meisten Gletscher in Ch'i-lien-Shan (Qilian Shan), dem Amne Machin (Anyemaqen) benachbart, in derselben Periode sich zurückzogen. Dieses Problem erscheint einer genaueren glaziologischen Untersuchung wert. Die Untersuchungen und Analysen ergaben weiter, dass der Halung (Halong) Gletscher zum Typ der ausbrechenden Gletscher gehört. Der Autor sagt versuchsweise den nächsten Ausbruch des Ha-lung (Halong) Gletscher sowie die Tendenz der Schwankungen der Gletscher in Ch'ilien Shan (Qilian Shan) für die nahe Zukunft voraus.

\section{INTRODUCTION}

The Qinghai-Xizang (Ch'ing-hai-Hsi-tsang) (Tibet) Plateau, with a total area of about $2.4 \times 10^{6} \mathrm{~km}^{2}$, approximately a quarter of the area of China, is the largest and highest plateau area on Earth and a spectacular research area for the world's scientists. Mt Amne Machin (Anyemaqen) and the Ch'i-lien Shan (Qilian Shan) lie to the north-east forming a natural divide between the glacier-permafrost of the plateau and the loess highlands.

The Amne Machin (Anyemaqen) Mountains (lat. 34-35 ${ }^{\circ} \mathrm{N}$., long. 99-101 ${ }^{\circ} \mathrm{E}$.) are $200 \mathrm{~km}$ long and $60 \mathrm{~km}$ wide. They form the eastern extension of the K'un-lun (Kunlun) Range where

\footnotetext{
* Wade-Giles: Wang Wen-ying.
} 
the Hwang Ho (Huanghe-Yellow) River makes a ring-shaped turn. Mt Amne Machin (Anyemaqen) also called Mt Chi-shih (Jishi) at $6282 \mathrm{~m}$ a.s.l. has two sister peaks at $6268 \mathrm{~m}$ and $6090 \mathrm{~m}$ respectively and some 18 other peaks all above $5000 \mathrm{~m}$ rising into the sky perennially snow-capped like guards at the gateway to the Ch'ing-hai-Hsi-tsang (Qinghai-Xizang) Plateau. Yaks and sheep graze below $4500 \mathrm{~m}$ and along the Hwang Ho (Huanghe) Rivers are forests and tracts of farmland.

On completion of the glacier inventory, it was found that there are 40 glaciers in the Amne Machin (Anyemaqen) region with a total area of about $150 \mathrm{~km}^{2}$ and a water storage of about $13.8 \times 10^{9} \mathrm{~m}^{3}$. The average height of the snow-line is $4926 \mathrm{~m}$ on the north-eastern slope and $5230 \mathrm{~m}$ on the south-western slope. Based on ground surveys and satellite and air-photo interpretation, 15 of the glaciers are advancing, 2 are retreating and the remaining 23 are stable or have variations less than $18 \mathrm{~m}$, within the error limits of the photogrammetric techniques used.

Table I clearly shows that the south-west-facing Ha-lung (Halong) and Wa-lo-ma (Walema) glaciers have advanced the most in the last 15 years; their firn basins connect directly to the main peak of Mt Amne Machin (Anyemaqen). The Yeh-ho-lung (Yiehelong) and Wei-ke-lo Tang-hsiung (Weigele Dangxiong) glaciers, both more than $7 \mathrm{~km}$ long, are retreating.

From the Ch'i-lien Shan (Qilian Shan) inventory (Lanzhou Institute of Glaciology and Cryopedology, Academia Sinica, 1981) we know that there are 2859 glaciers in this region with a total area of about $1973 \mathrm{~km}^{2}$ and a water storage of about $130 \times 10^{9} \mathrm{~m}^{3}$. Every summer about $1000 \times 10^{6} \mathrm{~m}^{3}$ of melt water flows to the Kansu (Gansu) Corridor irrigating some 10 million Chinese $m u\left(0.7 \times 10^{6} \mathrm{ha}\right)$ making up $14 \%$ of the total discharge and thus constituting a most important water resource for this dry region.

TABle I. Terminal variations of Glacier tongues in AmNe Machin (ANyemaQen) during 1966-81

\begin{tabular}{|c|c|c|c|c|c|c|}
\hline \multirow[b]{2}{*}{ No. } & \multirow{2}{*}{$\begin{array}{l}\text { Name of glacier } \\
\text { Pinyin form }\end{array}$} & \multirow{2}{*}{$\begin{array}{l}\text { Name of glacier } \\
\text { Wade-Giles form }\end{array}$} & \multirow[b]{2}{*}{ Direction } & \multirow{2}{*}{$\begin{array}{l}\text { Mean } \\
\text { length } \\
\mathrm{km}\end{array}$} & \multicolumn{2}{|c|}{$\begin{array}{c}\text { Terminal variations } \\
1966-81\end{array}$} \\
\hline & & & & & $\begin{array}{l}\text { Retreat } \\
\mathrm{m}\end{array}$ & $\begin{array}{c}\text { Advance } \\
\mathrm{m}\end{array}$ \\
\hline 5J355E1 & Yiehelong & Yeh-ho-lung & NE & 7.3 & -150 & \\
\hline 2 & & & NE & 1.0 & & +50 \\
\hline 3 & Halong & Ha-lung & NE & 8.0 & & +790 \\
\hline 4 & & & $\mathrm{E}$ & 1.0 & & $?$ \\
\hline 5 & Xiaoma & Hsiao-ma & E & 4.4 & & +300 \\
\hline 6 & & & $\mathrm{NE}$ & 3.8 & & +250 \\
\hline 7 & & & NE & 2.0 & & +300 \\
\hline 8 & & & $\mathrm{NE}$ & 1.6 & & +500 \\
\hline 9 & Weigele Dangxiong & Wei-ke-lo Tang-hsiung & W & 8.7 & -220 & \\
\hline 5J355D & & & & & & \\
\hline 1-9 & & & S-SW-E & & & stable \\
\hline 10 & & & NE & 1.6 & & +150 \\
\hline 11 & & & $\mathrm{NE}$ & 1.2 & & +150 \\
\hline 12 & Turiqing & T’u-jih-ch'ing & $\mathrm{N}$ & 0.8 & & +200 \\
\hline 13 & Walema & Wa-lo-ma & SW & 3.2 & & +430 \\
\hline 14 & & & SW & 2.2 & & +300 \\
\hline 15 & Gunma & Kun-ma & SW & 2.0 & & +250 \\
\hline 16 & & & SW & 2.4 & & +200 \\
\hline 17 & & & SW & 1.9 & & +150 \\
\hline 18 & & & SW & 2.4 & & +150 \\
\hline 19 & & & SW & 0.8 & & stable \\
\hline $\begin{array}{l}5 \mathrm{~J} 356 \mathrm{D} \\
1-12\end{array}$ & & & & & & stable \\
\hline
\end{tabular}


Since 1958, Chinese glaciologists, under Professor Shi Yafeng (i.e. Shih Ya-feng), have been investigating 31 glaciers in the Ch'i-lien (Qilian) mountains. Of these 21 retreated an average of $8.5 \mathrm{~m} / \mathrm{a}$ from 1956 to 1976 and eight $4.9 \mathrm{~m} / \mathrm{a}$ over the past 15 years. On the most recent expedition only two glaciers were found to be advancing; the Yang-lung he (Yanglonghe) hanging glacier and Ta-tu-ma (Daduma) glacier, located in the ice valley south of Changyeh (Zhangye). By August 1981 the latter had advanced about $250 \mathrm{~m}$ over the previous 20 years.

The Ch'i-lien Shan (Qilian Shan) glacier inventory also showed that the Turgen-Kakitu Range, located near the northern edge of the Tsaidam Basin, and with an average annual precipitation of less than $100 \mathrm{~mm}$, holds $21 \%$ of the total glacierized area and $25.5 \%$ of the total water storage. The northern slope of the Ch'i-lien Shan (Qilian Shan) has 76.7\% of the glaciers with an area of $1335 \mathrm{~km}^{2}$. This area thus accounts for two-thirds of all the glaciers and the glacierized area of the Ch'i-lien Shan (Qilian Shan). The investigation of glacier variations in this region is extremely important because glacier melt water is used for agriculture, forestry, animal husbandry, and fisheries in the Kansu (Gansu) Corridor, because most of the glaciers have been retreating over the past 20 years, because the rate of retreat on the northern slope, with most of the glaciers, is about twice that of the southern slope, and because human impacts on the environment have led to reduction and degradation of other surface-water and ground-water supplies.

Although the main objectives of the Sino-German Joint Expedition were landscape and climatic geomorphology, studies of glaciers and their variations were included. The team not only investigated the Yang-lung he (Yanglonghe) and Leng-lung Ling (Lenglong Ling) glacier regions on the northern slope, where glaciologists have worked for many years, but also the flattopped glaciers in the Kakitu to the south-west, a region never before visited by glaciologists. Other observations in the Hsi-ta-t'an (Xidatan) region, in the K'un-lun (Kunlun) mountains, permit a more realistic comparison between the glaciers of the Ch'i-lien Shan (Qilian Shan) and the Amne Machin (Anyemaqen).

\section{HA-LUNG (HALONG) GLACIER}

"The falling of one leaf heralds the autumn." Ha-lung (Halong) glacier was selected as representative of the Amne Machin (Anyemaqen) because it is a large glacier connected to the main peak and because Shigeo Suizu, a member of the Japanese Toetsu Mountaineering Association for Anyemaqen Expedition 1981, had made a lot of measurements on it prior to the Sino-German expedition and was able to provide data on movement, accumulation, ablation, ice temperatures, and density.

\section{(a) Glacier movement}

The survey points established on Ha-lung (Halong) glacier by Suizu were augmented for the measurement of velocity and mass balance. Points were established around the snout for the measurement of glacier variations. Figure 1 shows the results of the ice-velocity measurements for the lower part of the glacier and Figure 2 the longitudinal change in ice velocity along the central flow-line.

Since 1966 the glacier has advanced $790 \mathrm{~m}$ and is still advancing. Based on its sudden rapid movement and cat-claw-like terminus it has been classified as a surging glacier (Fig. 3). Figures 1 and 2 show an area of rapid movement of up to $83 \mathrm{~m} / \mathrm{a} 3 \mathrm{~km}$ from the terminus and an area $1.5 \mathrm{~km}$ down glacier with a maximum movement of only $5 \mathrm{~m} / \mathrm{a}$. These differences create a 


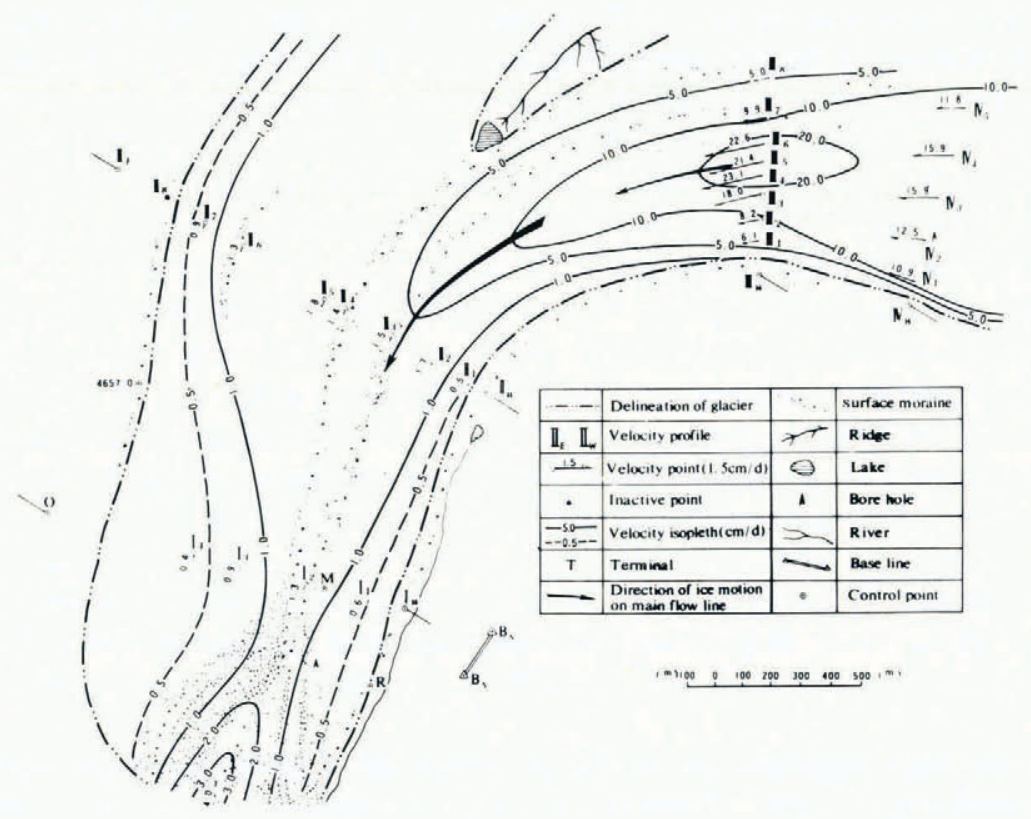

Fig. 1. Isopleth of ice velocity in the lower portion of Ha-lung (Halong) glacier.

high emergence velocity which counteracts in whole or in part the surface lowering due to ablation. The kinematic wave consists of potential and kinetic energy with a velocity much faster than the general movement velocity of the glacier. A ratio $C_{\mathrm{w}}$ was established between the normal and kinematic flow rates based on an advance of $790 \mathrm{~m}$ in 15 years and an annual velocity at the terminus of $4 \mathrm{~cm} / \mathrm{d}$ in 1981 , as follows:

$$
C_{\mathrm{W}}=\frac{790}{15} \times \frac{1}{365 \times 0.04}=3.6
$$

i.e. the kinematic wave is at least 3.6 times faster than the general movement velocity of the glacier.

\section{(b) Accumulation and ablation}

The snow-line on Ha-lung (Halong) glacier is at about $4860 \mathrm{~m}$ a.s.l. where three ice

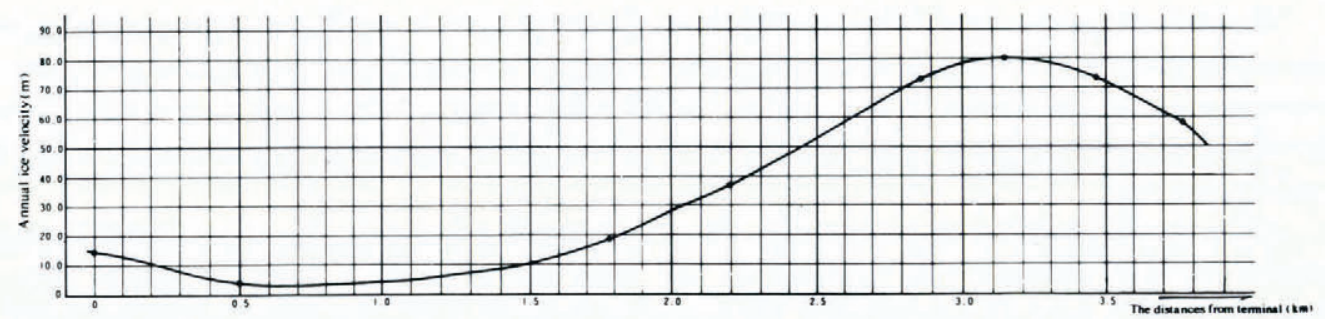

Fig. 2. Longitudinal change of annual velocity on main flow-line of Ha-lung (Halong) glacier ( $m / a)$. 


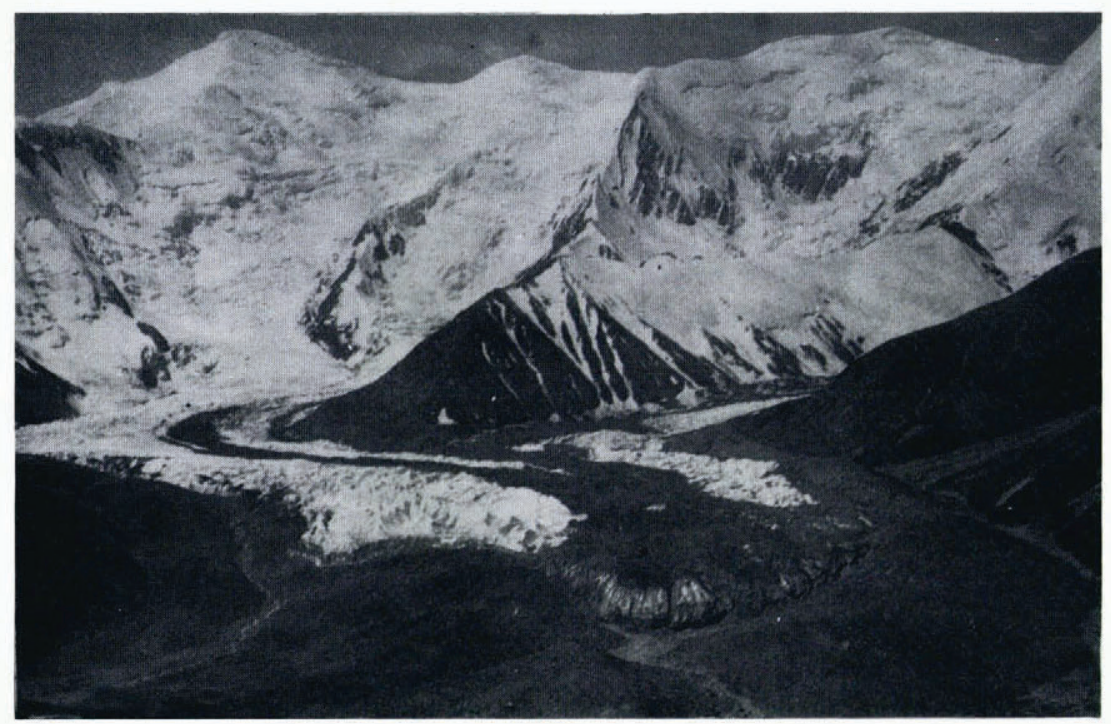

Fig. 3. Ha-lung (Halong) glacier.

layers were measured having a total thickness of $175 \mathrm{~cm}$. After considering evaporation the mean annual precipitation near the snow-line is estimated at $800 \mathrm{~mm}$ water equivalent. Ablation rates obtained were as follows: $31.7 \mathrm{~mm} / \mathrm{d}$ at the terminus and $29.2 \mathrm{~mm} / \mathrm{d}$ at a profile about $300 \mathrm{~m}$ below the snow-line. Owing to frequent blowing snow and its instantaneous melting during the period of observation the total ablation should include an average of $6 \mathrm{~mm} / \mathrm{d}$ of precipitation.

\section{(c) Density, ice temperatures, and snow-line}

Ice samples were taken near the terminus of the glacier and the gas bubbles in them were found to change from ball-shaped near the snow-line to olive- or silkworm-shaped at the terminus. The ice was clean with a density of $0.89 \mathrm{Mg} / \mathrm{m}^{3}$.

Two bore holes were made with the Lanzhou Institute steam drill; a $10 \mathrm{~m}$ hole in the pyramid area near the terminus and a $7.3 \mathrm{~m}$ hole at $4900 \mathrm{~m}$ near the snow-line. At $7-8 \mathrm{~m}$ depth ice temperatures were as low as $-6.5^{\circ} \mathrm{C}$ to $-7.2{ }^{\circ} \mathrm{C}$ (Fig. 4). The height of the snow-line changes with aspect; $4850 \mathrm{~m}$ on the north-eastern slope and $5100 \mathrm{~m}$ on the south-western slope.

The general characteristics of Ha-lung (Halong) glacier are quite different from those of neighbouring glaciers in the Ch'i-lien Shan (Qilian Shan) yet are surprisingly similar to those of glaciers in the Himalaya and K'un-lun Shan (Kunlun Shan), a problem meriting further investigation.

\section{(d) Future behaviour of the Ha-lung (Halong) glacier}

During 1974-75 the Chinese Glacier Investigation Group prepared a forecast for Batura Glacier, in the Pakistan Karakoram, and made a successful field test in 1978 (Ba-tuo-la Bingchuan Kao-cha-zu, 1982). In 1981, data were obtained for Ha-lung (Halong) glacier from which it is possible to forecast its future behaviour. 


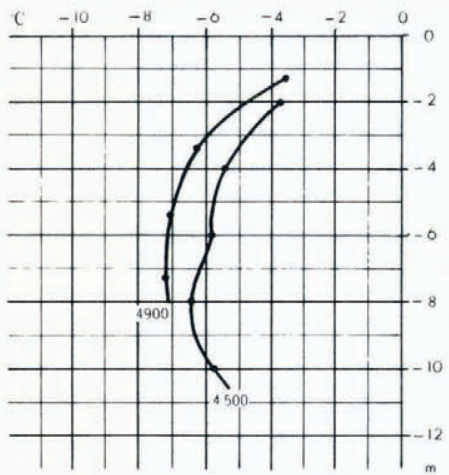

Fig. 4. Temperature of ice in Ha-lung (Halong) glacier: 4900 - bore hole at altitude of $4900 \mathrm{~m}, 4500$ - bore hole at altitude of $4500 \mathrm{~m}$.

The direction of the glacier bed is taken as the $X$-coordinate and the elevation perpendicular to the bed as the $Y$-coordinate. The intersecting point of the snow-line and the main glacier flowline is drawn on the $Y$-axis and then the longitudinal profile of the main flow-line is plotted in the coordinate system. The thickness, estimated by Lagally's formula (Lagally, 1930), is about $200 \mathrm{~m} 2.5 \mathrm{~km}$ from the snout. The emergence rate and mass balance were measured below the snow-line. Generally, the emergence velocities and ablation rates increase down glacier, the former tending to increase the surface height and the latter to decrease it. The combination of these two provides the future glacier surface and a comparison with the existing glacier permits a forecast of future variations. Substituting data from Ha-lung (Halong) glacier, estimating future rates of ablation, and assuming that the period of the propagation of the kinematic wave from the high velocity area to the snout was 15 years, then

$$
Y_{\mathrm{E}}=V(\tan \alpha \pm \tan \theta)
$$

where $V$ is the glacier velocity $(73 \mathrm{~m} / \mathrm{a}), \alpha$ is the slope angle of the ice surface $(0.1)$, and $\theta$ is the intersecting angle of the vector of movement relative to the ice surface, negative below and positive above $(+0.05)$.

The increase in ice thickness at the snout after 15 years would be $164 \mathrm{~m}$. The ablation value for the same period is calculated as follows:

$$
Y_{\mathrm{A}}=-\frac{1}{2}((0.038 \mathrm{~m} \times 365) \times 15)=-104 \mathrm{~m} .
$$

So, the variation in height of the terminus after 15 years would be $164-104=+60 \mathrm{~m}$. Figure 5 shows the simulated glacier profile and the evidence for the July 1981 prediction that "Halong Glacier will continue to surge in the next one to two decades" (Wang, 1982).

\section{5Y416G4 GLACIER IN LENG-LUNG LiNG (LENGLONG LiNG)}

The Leng-lung Ling (Lenglong Ling) Range is situated at the eastern end of the Ch'i-lien Shan (Qilian Shan). It is the most easterly glacierized region and one in which Chinese glaciologists have been working for the past 23 years. Temporary surveying stations were established on the glaciers in 1963-64 and 1976 for systematic observations. In 1981, the SinoGerman Joint Expedition continued studies on these glaciers. 


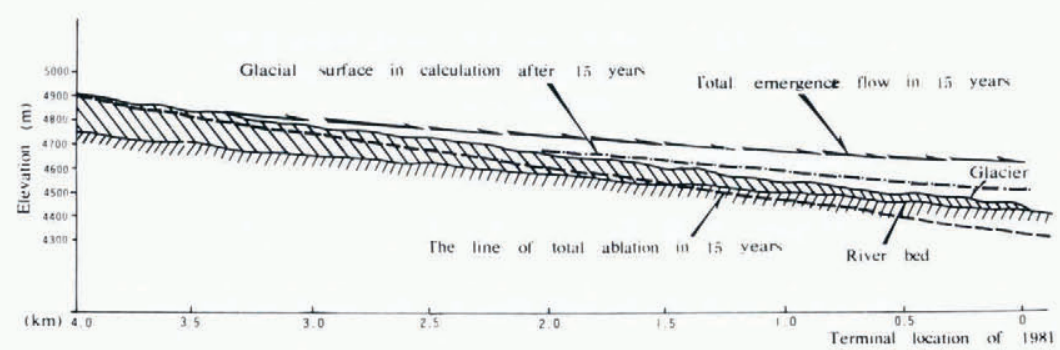

Fig. 5. A sketch showing the trends of terminal variation on Ha-lung (Halong) glacier.

\section{(a) Glacier movement}

In 1963, two velocity profiles were established across 5Y416G4 glacier, one at the terminus and the other near the snow-line, then at about $4450 \mathrm{~m}$ a.s.l. Due to very low flow rates results from the former are considered unreliable, those from the latter are given in Table II.

In 1981 the profile near the snow-line could not be established due to bad weather. Wooden subtense bars were set in the ice at the terminus and provided the measurements for three days shown in Table III. Comparison between these data and those for 1963 showed velocities had increased and were about two times greater than those for No. 1 glacier in the T'ien Shan (Tian Shan) in 1973 (Wang and others, 1976).

\section{(b) Glacier mass balance}

Table IV shows the glacier mass balance for 5Y416G4 glacier from 1962 to 1981 (Zhongguo Ke-xue-yuan Lanzhou Bing-chuan Dong-tu Yan-jiu-suo, Qilian Shan Bing-xue Liyong Yanjiu-dui, 1980). Apart from the negative balance of $-53 \mathrm{~mm}$ for $1962-63$ the rest of the balances are positive.

\section{(c) Glacier temperatures and density}

In 1976 a $10 \mathrm{~m}$ bore hole was drilled and gave a minimum temperature of $-4{ }^{\circ} \mathrm{C}$ at a depth of $4 \mathrm{~m}$ in the Ch'i-lien Shan (Qilian Shan). Based on many samples the mean ice density was found to be $0.9 \mathrm{Mg} / \mathrm{m}^{3}$, marginally denser than that of Ha-lung (Halong) glacier.

\section{(d) Glacier variations}

Observations on the fluctuation of the tongue of 5Y416G4 glacier have been made for the past 25 years and ice-core analysis has provided data on the annual accumulation rates over the past 82 years for the Kakitu flat-topped glacier 5Y564A. Figure 6 shows a comparison between the last 30 years of data for the latter and the 25 years from the former. It shows that the terminus of 5Y416G4 glacier retreated rapidly from 1964 to 1976 but that this rate slowed

TABLE II. Velocities AT THE CROSS-PROFILE IN FIRN OF 5Y416G4 GLACIER DURING 1963

$\begin{array}{lccccccc}\begin{array}{l}\text { No. of poles } \\ \text { (west to east) }\end{array} & 1 & 2 & 3 & 4 & 5 & 6 & 7 \\ \text { Velocity, m/a } & 3.1 & 1.7 & 2.8 & 7.9 & 23.8 & 2.1 & 2.5\end{array}$


TABLE III. Velocities AT THE CROSS-PROFILE ON THE GLACIAL TERMINUS OF 5Y416G4 GLACIER DURING 1981

$\begin{array}{lllll}\begin{array}{l}\text { No. of poles } \\ \text { (west to east) }\end{array} & 1 & 2 & 3 & 4 \\ \text { Glacial velocity, m/a } & 1.8 & 4.4 & 4.0 & 1.5\end{array}$

TABLE IV. MASS BALANCE OF 5Y416G4 GLACIER (1962-81)

\begin{tabular}{|c|c|c|c|c|c|c|c|c|}
\hline \multirow{2}{*}{$\begin{array}{l}\text { Glacial } \\
\text { area } \\
\mathrm{km}^{2}\end{array}$} & \multirow{2}{*}{$\begin{array}{l}\text { Observed } \\
\text { years }\end{array}$} & \multirow{2}{*}{$\begin{array}{l}\text { Height of } \\
\text { of snow line } \\
\mathrm{m}\end{array}$} & \multicolumn{2}{|c|}{ Net accumulation } & \multicolumn{2}{|c|}{ Net ablation } & \multicolumn{2}{|c|}{ Balance } \\
\hline & & & $\begin{array}{l}\text { Area } \\
\mathrm{km}^{2}\end{array}$ & $10^{4} \mathrm{~m}^{3}$ & $\begin{array}{l}\text { Area } \\
\mathrm{km}^{2}\end{array}$ & $10^{4} \mathrm{~m}^{3}$ & $10^{4} \mathrm{~m}^{3}$ & $\begin{array}{l}H \\
\mathrm{~mm}\end{array}$ \\
\hline 1.40 & $1962-63$ & 4450 & 0.82 & 28.7 & 0.58 & 36.2 & -7.5 & -53 \\
\hline 1.36 & $1975-76$ & 4420 & 0.92 & 45.9 & 0.44 & 8.4 & +37.5 & +276 \\
\hline 1.36 & $1976-77$ & 4430 & 0.76 & 38.0 & 0.60 & 28.0 & +10.0 & +73 \\
\hline 1.35 & $1977-81$ & 4300 & 0.85 & 42.6 & 0.59 & 28.5 & +14.1 & +103 \\
\hline
\end{tabular}

between 1976 and 1981. On the flat-topped glacier in Kakitu there was a steady increase in the thickness of ice layers from 1971, especially so since 1977. This reflects the continually increasing annual precipitation which is also reflected in the positive glacier mass balances for the majority of glaciers surveyed. Analysis shows a lag of about 15 years for the glacier responding to changing weather so that the forecast change from glacier retreat to advance within the next 15 years is reasonable.

\section{CONCLusion}

This paper has reported on glacier variations in the north-eastern part of the Ch'ing-hai-Hsitsang (Qinghai-Xizang) Plateau and predicts the trend of glacier variations for the near future.

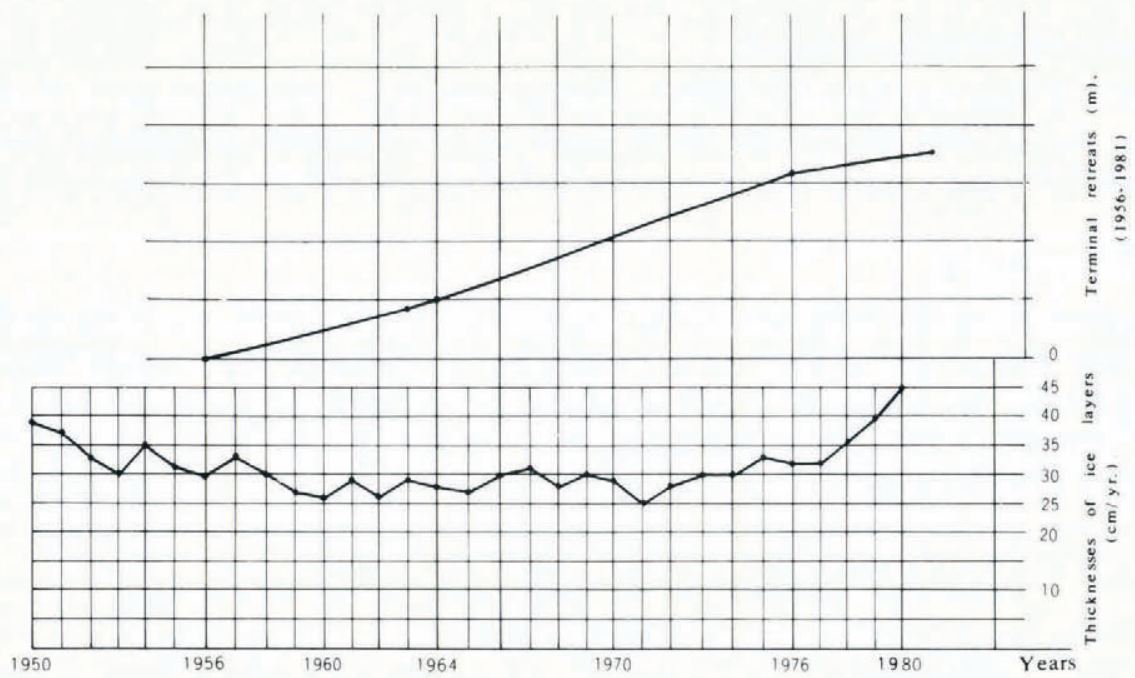

Fig. 6. Above - terminal retreats of 5Y416G4 glacier, 1956-81. Below - thicknesses of ice layers of 5Y564A flattopped glacier of Kakitu. 
(a) The Sino-German Joint Expedition to the Ch'ing-hai-Hsi-tsang (Qinghai-Xizang) Plateau established the first system of fixed and mobile observation stations. Forty glaciers in the Amne Machin (Anyemaqen) Mountains were investigated and their inventory completed; 15 were advancing, 2 retreating and the remainder stable. Basically, the advancing glaciers are in the centre of the Amne Machin (Anyemaqen) Massif and the two retreating glaciers on either end showing that glacier activity is not synchronous.

(b) Of the 31 glaciers in the Ch'i-lien Shan (Qilian Shan) measured, 29 have been retreating during the past $15-25$ years and two little ones advancing. This is almost the opposite situation to that in the Amne Machin (Anyemaqen) Massif and calls for further investigation.

(c) The glacier inventory analysis and field studies show that aspect is an important factor in glacier distribution. The longer glaciers and the most heavily glacierized areas are found along the north-easterly slopes.

(d) Strong evidence was found for a link between climatic change and glacier response on Ha-lung (Halong) glacier. It is forecast that this glacier will continue to advance with a surge coming within 10-20 years. A systematic study of data from 5Y416G4 glacier, of Leng-lung Ling (Lenglong Ling) in the Ch'i-lien Shan (Qilian Shan), and other field observations indicate that most of the retreating glaciers in the Ch'i-lien Shan (Qilian Shan) will be advancing within 15 years.

MS. received 7 July 1982 and in revised form 15 October 1982

\section{REFERENCES}

Ba-tuo-la Bing-chuan Kao-cha-zu [i.e. Pa-t'o-la Ping-ch'uan K'ao-ch'a-tsu]. 1982. Pa-t'o-la ping-ch'uan te pien-hua yu-pao chi ch'i yen-cheng [Forecast of variations of Batura Glacier and its proof]. (In Chung-kuo Ti-li Hsueh-hui ping-ch'uan tung-t'u hsueh-shu hui-yi lun-wen hsuan-chi (ping-ch'uan hsueh) [Symposium on glaciology and cryopedology (glaciology) at the meeting of the China Geography Society]. Peking, K'e-hsueh Ch'u-pan-she, p. $33-36$.

Lagally, M. 1930. Die Zähigkeit des Gletschereises und die Tiefe der Gletscher. Zeitschrift für Gletscherkunde, Bd 18, Ht. 1-3, p. 1-8.

Lanzhou Institute of Glaciology and Cryopedology, Academia Sinica. 1981. Glacier inventory of China. I. Qilian [i.e. Ch'i-lien] Mountains. Lanzhou [i.e. Lan-chou], Lanzhou Institute of Glaciology and Cryopedology, Academia Sinica.

Wang Wenying [i.e. Wang Wen-ying]. 1982. The Anyemaqen [i.e. Amne Machin] Mountains. China Reconstructs, Vol. 31, No. 2, p. 40-43.

Wang Wenying [i.e. Wang Wen-ying] and others. 1976. 1962-1973 T'ien Shan Wu-lu-mu-ch'i he yi-hao ping-ch'uan te hou-t'ui he yun-tung te tui-pi ts'e-liang [The retreat of No. 1 glacier of Urumchi river, T'ien Shan, 1962-1973, and the comparative surveying of its movement]. [By] Wang Wenying [i.e. Wang Wen-ying], Liu Jinghuang [i.e. Liu Ching-huang], Luo Xiangrui [i.e. Lo Hsiang-jui], You Genxiang [i.e. You Ken-hsiang|. Chung-kuo K'e-hsuehyuan Lan-chou Ping-ch'uan Tung-t'u Sha-mo Yen-chiu-so. Chi-k'an, [No.] 1, p. 32-35.

Zhong-guo Ke-xue-yuan Lanzhou Bing-chuan Dong-tu Yan-jiu-suo, Qilian Shan Bing-xue Liyong Yan-jiu-dui [i.e. Chung-kuo K'e-hsueh-yuan Lan-chou Ping-ch'uan Tung-t'u Yen-chiu-so, Ch'i-lien Shan Ping-hsueh Li-yung Yenchiu-tui]. 1980. Ch'i-lien Shan ping-ch'uan-te chin-ch'i pien-hua [A preliminary study on recent fluctuation of glaciers in the Ch'i-lien Shan]. Acta Geographica Sinica, Vol. 35, No. 1, p. 48-57. [English summary, p. 57.] 